\title{
Pengaruh daya tarik Foto Wajah pada tampilan rupa kemasan Lay's terhadap minat berfoto konsumen di kota Bandung
}

\author{
Egi Anwari' ${ }^{1}$, Florencika Mayumi Tawaang² \\ Institut Teknologi Harapan Bangsa, prodi Desain Komunikasi Visual \\ Jl. Dipatiukur No. 80 - 84, Bandung, Jawa Barat \\ Email : ${ }^{1}$ anwariegi@gmail.com , ${ }^{2}$ florencika.mayumi.t@gmail.com
}

\begin{abstract}
ABSTRAK
Fungsi kemasan bukan hanya untuk mewadahi produk, namun fungsinya telah bertambah, dan saat ini banyak dimanfaatkan oleh produsen untuk menarik perhatian konsumen. Kemasan makanan dari berbagai brand dipajang di rak-rak pasar swalayan dan saling bersaing untuk merebut perhatian konsumen. Salah satu yang menarik perhatian adalah kemasan keripik kentang Lay's yang terlihat berbeda dan kontras dengan para pesaingnya. Tampilan rupa (visualisasi) kemasan keripik kentang Lay's berubah dari biasanya. Gambar kentang dan tampilan logo yang dominan, diganti dengan foto setengah wajah yang sedang tersenyum. Tampilan foto yang mencolok pada kemasan Lay's ternyata menarik perhatian konsumen untuk melakukan aksi swafoto. Tampak bahwa pihak produsen menangkap perilaku masyarakat yang sedang menyukai swafoto, untuk mengikuti program promosi penjualan (sales promotion) produk keripik kentang Lay's. Daya tarik visual foto wajah pada kemasan Lay's menjadi fokus dalam penelitian ini dan dikaitkan dengan tindakan konsumen untuk melakukan aksi swafoto. Metode analisis visual dikaitkan dengan metode AISAS (Attention, Interest, Search, Action, Share) menjadi acuan dalam penelitian ini, untuk mengetahui bagaimana daya tarik foto mempengaruhi perilaku konsumen untuk melakukan swafoto. Hasil penelitian ini memperlihatkan hubungan antara unsur rupa pada kemasan dan ketertarikan konsumen untuk melakukan aksi. Tampilan foto setengah wajah tersenyum pada kemasan Lay's mampu mengajak konsumen untuk melakukan swafoto dan mengunggahnya ke akun facebook resmi Lay's atau media sosial lainnya.
\end{abstract}

Kata Kunci: Visual Kemasan, Daya Tarik Foto, Swafoto. 


\begin{abstract}
Today, producer utilizes the function of packaging not only to accommodate the product, but also to attract the attention of consumers. Food packagings from various brands are displayed in the supermarket shelves and competing for grabbing the attention of consumers. One of the highlights is Lay's potato chip packaging that looks different and contrasts with its competitors. The visual appearance of layers of Lay's potato chips changed from the usual. Potato image and dominant logo display, replaced with half smiling face photo. The striking display of photos on Lay's packaging has evidently attracted the attention of consumers to take swafoto. It appears that the producers catch the behavior of people who like swafoto, to follow the sales promotion program of Lay's potato chip products. The visual attractiveness offacial photos on Lay's packaging becomes the focus of this research and is linked to consumer actions to take swafoto. Visual analysis method is related to AISAS method become references in this research, to reveal how the attraction of photo influences consumer behavior to do swafoto. The results of this study show the relationship between the elements in the packaging and the consumer interest to perform the action. Half smiling face photo display on Lay's packaging is able to invite consumers to take swafoto and upload it to the official facebook account of Lay's or other social media.
\end{abstract}

Keywords: Visual Packaging, Photo attractiveness, Swafoto.

\section{PENDAHULUAN}

Di era persaingan brand yang semakin ketat, berbagai macam bentuk komunikasi brand bermunculan di pasar untuk bersaing satu sama lain. Banyak cara dilakukan oleh produsen untuk mengkomunikasikan brand melalui bentuk komunikasi pemasaran yang sudah direncanakan, seperti melalui periklanan, mengadakan brand activation, atau melakukan promosi tertentu yang bisa menaikan tingkat kesadaran konsumen akan sebuah brand.

Salah satu bentuk kegiatan promosi yang sering dilakukan produsen adalah sales promotion atau promosi penjualan. Dalam melakukan promosi penjualan, produsen biasanya memberikan semacam harapan atau janji kepada konsumen, seperti penawaran khusus, memberikan keuntungan yang lebih, penawaran hadiah, atau berbagai cara yang dapat membuat konsumen tertarik dan senang. Bentuk promosi penjualan yang sering dilakukan adalah memberi potongan harga serta mendapatkan barang gratis dalam pembelian jumlah yang banyak.

Melalui kegiatan promosi penjualan, ada salah satu upaya produsen untuk menarik perhatian konsumen yang berkaitan dengan kemasan, yakni bagaimana konsumen segera tertuju pada tampilan rupa kemasan yang berbeda dari biasanya. Di pasar swalayan, deretan rak tempat berbagai produk dipajang menjadi ajang persaingan antar brand. Salah satu kunci untuk menarik perhatian konsumen adalah dengan 
membuat tampilan rupa kemasan yang berbeda dan terlihat kontras dengan pesaingnya. Setiap brand dengan ciri khas produk masing-masing akan terlihat mencolok karena perupaan kemasan akan membuat mata konsumen terpancing untuk melihat pada kemasan tersebut.

Menciptakan sesuatu untuk menarik perhatian konsumen tidak mudah, apalagi banyak produk yang hamper mirip, sehingga brand menjadi penting untuk mampu membedakan dengan pesaing. Dalam posisi ini konsumen harus memilih sesuai dengan kebutuhan mereka atau cenderung menentukan pilihan pada sebuah brand yang sudah terpercaya atau terkenal. Selain brand yang terpercaya, konsumen juga dihadapkan pada pilihan lain yang menarik perhatian. Contohnya brand-brand makanan yang dikemas dengan tampilan rupa tertentu, mulai dari makanan pokok sampai makanan ringan, semua memiliki ciri khas dan keunggulan tersendiri.

Tampilan rupa kemasan yang awalnya hanya untuk membantu menginformasikan isi atau memperindah tampilan luar, berkembang menjadi salah satu cara untuk mengkomunikasikan bagaimana sebuah brand dapat mengajak atau berinteraksi dengan konsumennya. Perkembangan tersebut terlihat pada kemasan yang memberikan pesan atau janji-janji yang akan membuat konsumen melakukan suatu tindakan tertentu. Seperti memberikan "extra free" atau tambahan gratis pada isi kemasan aslinya sehingga konsumen tertarik untuk melakukan pembelian karena tawaran yang diberikan.

Salah satu yang menjadi objek kajian dalam penelitian ini adalah produk keripik kentang Lay's yang diproduksi oleh PT. Indofood Fritolay Makmur. Lays sudah lebih terkenal diluar sebelum dipasarkan di Indonesia. Ketika pertama kali diluncurkan di Indonesia, kemasan produk keripik kentang Lay's hanya menampilkan sebuah gambar dari isi produk tesebut dan didominasi oleh warna-warna yang mewakili masing-masing rasa. Namun pada bulan November tahun 2016, produk kripik kentang Lay's mengeluarkan desain kemasan terbaru, dengan foto setengah wajah orang yang tersenyum lebar di bagian depan kemasan.

Lay's mengeluarkan kemasan tersebut dalam program sales promotion dengan menggunakan tanda pagar (hashtag) \#SenyumBersamaLays yang disebarkan melalui akun sosial facebook resmi mereka "Lay's Indonesia" dan menawarkan hadiah berupa uang tunai. Program tersebut mengajak para konsumen untuk berfoto bersama produk Lay's seunik dan sekreatif mungkin, kemudian diunggah di akun resmi. Tiap harinya penyelenggara akan memilih satu orang yang berhak untuk menjadi pemenang. Program ini dilakukan dalam jangka waktu kurang lebih 3 bulan dari awal November 2016 hingga akhir Februari 2017 sesuai dengan tanggal yang telah ditetapkan. Program tersebut bisa berjalan baik seiring dengan respon positif dari konsumen yang mengikuti kegiatan.

Pengaruh foto wajah tersenyum pada kemasan Lay's terhadap minat berfoto konsumen menarik untuk diteliti mengingat fungsi desain kemasan yang lebih meluas. Kemasan yang awalnya hanya sebagai wadah untuk melindungi isi, terus berkembang dengan menambahkan beberapa unsur rupa dengan tujuan tertentu. Kemasan makanan ringan Lay's menampilkan perwajahan yakni foto setengah wajah yang tersenyum lebar dibagian depan kemasan (bagain display utama kemasa). Konsumen diajak untuk 
berinteraksi dengan kemasan Lay's terbaru dan segera melakukan suatu tindakan yakni berfoto bersama dengan kemasan tersebut.

\section{TINJAUAN TEORITIK}

\subsection{Kemasan}

Peran kemasan pada dasarnya untuk mengemas dan melindungi barang atau isi sehingga mudah untuk dibawa kemanamana. Namun ketika pasar swalayan mulai bermunculan, kemasan menjadi hal mendasar untuk mengkomunikasikan informasi isi kemasan kepada konsumen. Melalui cara berbelanja di pasar swalayan, konsumen tidak memiliki saluran untuk berkomunikasi atau tepatnya menawar harga barang dengan pihak penjual. Dalam konteks tersebut, desain kemasan menjadi penting dan memiliki nilai strategis untuk membujuk konsumen.

Fungsi kemasan menjadi meluas, karena konsumen yang semakin paham akan senantiasa membaca informasi penting pada kemasan. Bukan hanya sekedar membaca tanggal kadaluarsa, namun mereka akan membaca kandungan atau komposisi yang tertera pada kemasan. Merujuk pada (Julianti, 2004:15) beberapa fungsi kemasan yang berkaitan dengan penelitian ini adalah sebagai sarana komunikasi produk dan branding kepada konsumen. Selanjutnya kemasan dapat menjadi pemicu minat beli dengan merangsang lima panca indra konsumen, yaitu melihat, mendengar, membau, meraba, merasa, sampai ada keputusan membeli dan menggunakan produk.

Kemasan yang ideal harus mempunyai kemampuan untuk memikat konsumen, bahkan menarik konsumen untuk membeli. Selain memberi informasi, tampilan rupa kemasan biasanya digunakan sebagai sarana promosi. Sebuah kemasan selain harus menunjukkan sisi estetik dari produk tersebut, juga memiliki kepentingan ketika program pemasaran menuntut fungsi yang lebih. Kepentingan desain dan kepentingan pemasaran harus saling mendukung.

\subsection{Desain Kemasan}

Sebuah kemasan memiliki tampilan rupa sesuai dengan citra yang ingin disampaikan oleh brand masing-masing. Setelah fungsi utama kemasan untuk membungkus dan melindungi isi, pada akhirnya desain kemasan berperan dalam pemasaran produk dengan mengkomunikasikan kepribadian atau fungsi produk konsumsi secara unik (Klimchuk \& Krasovec, 2006:33).

Peran desain kemasan berkembang dan berganti sesuai dengan pesan dan strategi pemasaran yang dilakukan oleh para produsen. Semakin banyak brand yang ditujukan kepada konsumen, semakin banyak pula kemasan yang harus dapat membedakan satu sama lain dengan keunikan tersendiri. Umumnya tujuan desain kemasan untuk masing-masing produk atau brand tertentu, ialah (Julianti, 282, 2006):

1. Menampilkan atribut unik sebuah produk.

2. Memperkuat penampilan estetika dan nilai produk.

3. Mempertahankan keseragaman dan kesatuan merek produk.

4. Memperkuat perbedaan antara ragam produk dan lini produk.

5. Mengembangkan bentuk kemasan berbeda yang sesuai dengan kategori.

6. Menggunakan material baru dan mengembangkan struktur inovatif untuk 
mengurangi biaya, lebih ramah

lingkungan, atau meningkatkan

fungsionalitas.

Desain kemasan memiliki struktur dan tampilan rupa untuk setiap tujuan yang ingin dicapai, seperti salah satu contoh yaitu untuk promosi khusus atau dalam penelitian ini berkaitan dengan konteks promosi penjualan. Strategi untuk promosi khusus diantaranya dengan membuat kemasan khusus untuk kejadian tertentu atau disebut dengan seasonal pack, kemasan untuk promosi dengan hadiah tertentu, dan kemasan dengan isi lebih banyak untuk harga yang sama (extra volume). Kemasan ini fokus pada mengkomunikasikan promosinya, bukan berarti mengabaikan aspek informasi lain tentang produknya, namun pesan yang harus mendapat porsi terbesar adalah apa yang dipromosikan. (Wahyudi \& Satriyono, 2017:26). Desain untuk promosi khusus menjadi pembeda suatu kemasan dengan kemasan lainnya, sehingga didesain dengan pendekatan tersendiri.

Setiap kemasan harus menjadi unik serta mampu menarik perhatian konsumen untuk dapat bersaing dalam kompetisi produk di pasar. Selain itu, desain kemasan menjadi sarana berekspresi suatu daya tarik produk dengan mengkomunikasikan emosi, budaya, sosial, psikologi, dan informasi kepada konsumen. Setiap kemasan memiliki tujuan tersendiri, sehingga berbeda juga setiap elemen kemasan yang akan menjadi fokus utama. Studi rupa terhadap penentuan tipografi, garis, warna dan gambar yang khas dapat menjadi elemen-elemen desain yang penting dalam membentuk atribut komunikatif suatu desain kemasan untuk membedakan produk secara unik. Berikut adalah beberapa elemen-elemen desain kemasan (Klimchuk dan Krasovec, 2006:36) yang diurutkan sebagai berikut:

\section{Citra}

Citra berkaitan dengan persepsi, sehingga proyeksi yang disampaikan oleh tampilan rupa kemasan harus sesuai dengan harapan konsumen. Pencitraan digunakan dalam desain kemasan untuk memperlihatkan produk, menggambarkan konsumen target, menetapkan mood, menyediakan kredibilitas atau untuk menggugah selera.

\section{Gambar}

Gambar, apakah dalam bentuk ilustrasi atau foto harus mampu mengkomunikasikan atau menjelaskan suatu produk. Sebuah gambar dapat menarik perhatian konsumen dan membangkitkan selera makan. Fungsi foto maupun ilustrasi produk banyak digunakan untuk mendukung informasi visual mengenai produk, meyakinkan konsumen tentang bahan dasar produk, menunjukkan kualitas isi, dan membantu pengenalan produk.

Beberapa fungsi penggunaan ilustrasi atau foto akan membuat desain kemasan menjadi lebih menarik, mudah dipahami, dan lebih meyakinkan. Beberapa kemasan mencoba menampilkan foto model, foto artis atau public figure untuk menunjang kesan tertentu dari produk yang sesuai dengan target pengguna produknya (Wahyudi \& Satriyono, 2017:61).

Khusus untuk penggunaan foto pada kemasan, konsumen dibuat tertarik karena gambar secara fotografis diolah sedemikian rupa, sehingga mampu menggugah selera konsumen. Selain itu, kemampuan fotografi dapat berfungsi persuasif apabila mampu menggerakkan pikiran, perasaan, dan 
selanjutnya melakukan tindakan dengan cara tertentu sesuai yang dikehendaki komunikator (creator) (Harsanto, 2016:12). Maka sebuah foto dalam sebuah kemasan harus bersifat persuasif, seperti iklan yang mampu membujuk konsumen untuk mencoba produk yang ditawarkan sehingga menimbulkan rangsangan yang mengarah pada sikap atau perilaku yang sesuai dengan yang diharapkan.

\section{Tata letak}

Mengatur atau mengarahkan alur baca konsumen untuk memahami urutan kepentingan elemen yang paling utama hingga kebagian pendukung merupakan bagian dari tata letak dalam desain kemasan. Penempatan elemen-elemen rupa yang tepat dapat memberikan tampilan rupa yang menarik untuk konsumen. Berikut beberapa prinsip dasar hukum tata letak (Jefkins, 1995:245,) yaitu hukum kesatuan, hukum keberagaman, hukum keseimbangan, hukum ritme/irama, hukum keserasian, hukum keproporsionalan, hukum skala (perbandingan), dan hukum penekanan (penonjolan), yang dipakai dalam penelitian ini:

1) Hukum keberagaman, suatu tata letak harus ada suatu perubahan dan pengkontrasan dengan memanfaatkan ruang kosong dalam keseluruhan tata letak, bisa juga didapat dengan pemanfaatan gambar untuk menghindari kesan monoton.

2) Keseimbangan, prinsip yang menekankan pada bagaimana menata elemen-elemen visual terasa seimbang antara sisi kanan dan kiri, atau antara sisi atas dan bawah bidang desain. Keseimbangan tata letak dapat dicapai dengan dua strategis, pertama adalah keseimbangan simetris dimana peletakan elemen desain pada dua sisi sama persis. Kedua adalah keseimbangan asimetris dimana peletakan elemen desain tidak sama persis pada dua sisi namun secara keseluruhan tetap seimbang (Wahyudi \& Satriyono, 2017:64).

3) Penekanan, Aturannya adalah bila semua ditonjolkan, maka yang terjadi adalah tidak ada hal yang ditonjolkan. Hal ini berkaitan erat dengan hukum lainnya terutama hukum keberagaman dan skala.

\subsection{Teori Gestalt}

Salah satu teori yang berkaitan denagn unsur rupa pada kemasan dalam penelitian ini merujuk pada prinsip Gestalt. Kata Gestalt atau Gestaltung adalah kata dari bahasa Jerman yang berarti susunan (arrangement atau organization) yang bersifat menyeluruh (whole). Keseluruhan selalu lebih dari penjumlahan setiap bagian (The Whole is more than the sum of its parts) (Adityawan, 2010:108). Selanjutnya teori ini dikembangkan oleh Max Wertheimer yang menyatakan bagaimana persepsi manusia dalam melihat suatu objek biasanya dipengaruhi oleh susunan objek disekelilingnya. Pola presepsi tersebut dibagi dalam beberapa prinsip, yaitu :

1. Similarity, Pengelompokan berdasar pada kesamaan: bila kita melihat beberapa benda yang memiliki kesamaan bentuk, kita cenderung untuk melihatnya sebagai suatu kesatuan.

2. Proximity, Pengelompokan berdasar pada jarak atau kedekatan. Semakin dekat letak beberapa unsur, akan semakin kuat kita melihatnya sebagai sebuah kesatuan.

3. Continuation, Mata melihat akan mengikuti arah suatu garis atau sumbu. 
4. Closure, Bentuk-bentuk yang mudah dikenali namun tidak utuh akan dilihat dalam proses persepsi sebagai sebuah kesatuan yang utuh.

5. Figure/Ground, Proses persepsi manusia akan berusaha membedakan objek dari latar. Dalam keadaan yang sebanding, objek dan latar dapat ditukar sehingga menghasilkan hubungan ambiguitas atau mendua.

Persepsi yang diterapkan oleh Gestalt merupakan pertimbangan bagaimana manusia melihat sebuah objek dan memproses informasi yang tampilkan menjadi sebuah kesatuan yang utuh atau lengkap. Selain itu, Gestalt membantu memusatkan perhatian pada bagian kecil, versi foto yang dipotong sehingga tambahan lainnya bisa dipelajari ketika perhatian diarahkan ke keseluruhan gambar (Lester: 48, 2011). Kemasan dalam penelitian ini memiliki keterkaitan dari sisi Gestalt. Unsur gambar yang direkayasa sedemikan rupa dibuat untuk memancing perhatian konsumen.

\subsection{Perilaku Konsumen}

Perilaku konsumen didefinisikan sebagai tindakan yang langsung terlibat dalam mendapatkan, mengonsumsi, dan menghabiskan produk dan jasa, termasuk proses keputusan yang mendahului dan menyusuli tindakan ini (Engel, dkk, 1994:3). Selain itu (Hawkins, Best, dan Coney, 2007) dalam Suryani berpendapat bahwa perilaku konsumen merupakan studi tentang bagaimana individu, kelompok atau organisasi, dan proses yang dilakukan untuk memilih, mengamankan, menggunakan dan menghentikan produk, jasa, pengalaman atau ide untuk memuaskan kebutuhannya beserta dampaknya terhadap konsumen dan masyarakat.
Dari pengertian diatas, dapat disimpulkan bahwa perilaku konsumen bisa dianalisis dengan mempelajari atau mengamati apa yang diinginkan maupun dibutuhkan oleh konsumen. Hal tersebut juga tidak menentu karena dalam suatu kondisi, setiap konsumen memiliki ciri dan khas tersendiri yang dipengaruhi oleh diri sendiri, lingkungan sosial, budaya, atau pun ekonomi. Selain itu, perilaku konsumen juga dapat dipengaruhi oleh bauran pemasaran yaitu produk, harga, tempat dan promosi. Faktor-faktor tersebut yang dapat mempengaruhi keputusan konsumen dalam memilih sebuah produk.

Ada 5 proses bagaimana konsumen mengambil keputusan, yaitu :

\section{Mengenali kebutuhan.}

Pada tahap ini konsumen merasakan bahwa ada hal yang dirasakan kurang dan menuntut untuk dipenuhi. Konsumen menyadari bahwa terdapat perbedaan antara apa yang dialaminya dengan yang diharapkan.

\section{Mencari Informasi.}

Pencarian informasi ini akan berbeda tingkatannya tergantung pada persepsi konsumen atas resiko dari produk yang akan dibelinya. Konsumen umumnya mencari informasi dari berbagai sumber.

\section{Mengevaluasi alternatif.}

Informasi yang diperoleh dari berbagai sumber akan menjadi bahan pertimbangan bagi konsumen untuk mengambil keputusan. Konsumen akan mempertimbangkan manfaat termasuk keterpercayaan merk dan biaya atau resiko yang akan diperoleh jika membeli suatu produk. 
4. Mengambil keputusan.

Setelah melalui evaluasi dengan pertimbangan yang matang, konsumen akan mengambil keputusan. Ada dua faktor yang mempengaruhi keputusan membeli dan tujuan pembelian yaitu sikap orang lain, dan faktor situasional yang tidak dapat diprediksikan (tidak terduga).

\section{Evaluasi Paska pembelian.}

Setelah membeli, konsumen akan mengevaluasi atas keputusan dan tindakannya dalam membeli. Jika konsumen menilai kinerja produk atau layanan yang dirasakan sama atau melebihi apa yang diharapkan, maka konsumen akan puas dan sebaliknya jika konerja produk atau jasa yang diterima kurang dari yang diharapkan, maka konsumen akan tidak puas.

Semakin banyak brand yang beredar, persaingan pun semakin ketat. Sebuah brand membutuhkan pembeli yang setia agar dapat terus bertahan. Ada dua cara yang dapat dilakukan untuk mempengaruhi seseorang dalam memutuskan membeli produk, yaitu menyesuaikan atribut-atribut produknya dengan sikap konsumen yang telah ada atau dengan mengubah sikap konsumen (Phalosa, 2013:23).

\subsection{Model AISAS}

AISAS merupakan model perilaku konsumen yang dikembangkan oleh Dentsu perusahaan iklan besar di Jepang, berdasarkan perubahan dalam lingkungan informasi. AISAS terdiri dari Attention (perhatian), Interest (ketertarikan), Search (pencarian), Action (tindakan), dan Share (berbagi). Perubahan model perilaku ini terjadi seiring dengan perkembangan teknologi internet yang semakin pesat.
Proses AISAS bekerja ketika konsumen memperhatikan produk, jasa, atau iklan (Attention) dan menimbulkan keinginan (Interest) sehingga mencari atau mengumpulkan informasi (Search) tentang barang tersebut. Pencarian ini bisa didapatkan dari internet pada blog yang ditulis orang lain, situs perbandingan produk, dan laman resmi perusahaan, atau dengan berbicara pada keluarga atau teman yang telah menggunakan produk atau jasa tersebut. Konsumen kemudian membuat penilaian keseluruhan berdasarkan informasi yang dikumpulkan dan informasi yang diperkenalkan oleh perusahaan, mempertimbangkan komentar dan pendapat oleh orang yang telah membeli dan menggunakan produk atau jasa tersebut. Jika berhasil, hal tersebut menjadi keputusan tegas untuk melakukan pembelian (Action). Setelah membeli, konsumen menjadi pemancar informasi dari mulut ke mulut, dengan berbicara pada orang lain atau dengan mengirim komentar dan kesan ke internet (Sharing). (Sugimoto \& Andree, 2011:80).

\subsection{Promosi}

Setiap perusahaan berusaha untuk mencapai keberhasilan usaha dengan melakukan strategi yang baik dan tepat agar produknya bisa dikenal dan mendorong agar melakukan pembelian. Dibutuhkan komunikasi yang tepat agar pesan dapat tersampaikan dengan baik pada masyarakat. Promosi merupakan salah satu cara perusahaan agar bisa mencapai target. Biasanya promosi bersifat persuasif, membujuk.

Untuk menentukan strategi mana yang tepat, penentuan alat komunikasi dalam bauran promosi bisa membantu perusahaan untuk mencapai target yang ditentukan. 
Bauran promosi (Promotion mix) dipilah menjadi 4 alat (Cummins \& Mullin, 2004:27):

1. Iklan : ruang pada media cetak, situs dan luar ruang, serta waktu pada media siaran seperti radio dan televisi.

2. Promosi penjualan : insentif dan penawaran yang mendorong konsumen atau pelanggan berperilaku tertentu pada waktu tertentu.

3. Publikasi : informasi atau opini mengenai produk yang disampaikan oleh pihak ketiga.

4. Pemasaran langsung : "kehadiran" (hadir bisa dalam bentuk panggilan telepon, surat, email, atau kehadiran tenaga penjual langsung kepada pelanggan atau prospek dimana pelanggan bisa lansung memberi respon).

\subsection{Promosi Penjualan}

Promosi penjualan adalah suatu proses yang menfokuskan pada perilaku dalam dua cara yang berbeda, yaitu promosi harga seperti beli satu dapat dua atau potongan harga, dan promosi nilai seperti undian atau gratis biaya pengiriman. Keduanya bertujuan untuk memberikan konsumen hal yang menyenangkan dan sesuatu yang bermanfaat bagi mereka. Terdapat 10 tujuan utama promosi yang ingin dicapai melalui promosi penjualan (Cummins \& Mulllin, 2004:35) :

1. Meningkatkan volume

2. Meningkatkan pembelian coba-coba (trial)

3. Meningkatkan pembelian ulang (repeat purchase)

4. Meningkatkan loyalitas

5. Memperluas kegunaan

6. Menciptakan ketertarikan

7. Menciptakan Kesadaran (awareness)

8. Mendapat dukungan dari pihak

\author{
perantara (intermediary) \\ 9. Melakukan dikriminasi para \\ pengguna.
}

Tidak ada promosi yang dilakukan untuk memberikan kerugian pada konsumen. Dengan memberikan keuntungan tertentu yang ditawarkan, konsumen akan merasa senang dan untung dengan tawaran yang diberikan. Promosi penjualan juga dapat memberikan nilai lebih untuk menjadi pertimbangan konsumen dalam menentukan pilihan.

\section{URAIAN PENELITIAN}

Lay's merupakan makanan ringan/ snack keripik yang berbahan dasar kentang kemudian diberikan bumbu perasa yang bermacam-macam. PT. Indofood Fritolay Makmur resmi menjadi perusahaan patungan pada tahun 2010 namun sebelumnya sudah memulai kegiatan usaha bersama di bidang makanan ringan sejak tahun 1990. Produk makanan ringan yang diproduksi oleh PT. Indofood Fritolay Makmur diantaranya adalah Chiki, Cheetos, Chitato, Jetz, Qtela dan lain-lainnya.

Motto yang berasal dari PT. Indofood Fritolay Makmur "Good Fun!" sebagai tagline utama memberikan pengaruh pada tiap lini produk yang dihasilkan. Lay's sendiri ingin memberikan citra ceria yang bisa membuat konsumen tersenyum ketika menikmati snack ini melalui ragam desain kemasannya.

Varian rasa Lay's di Indonesia tersedia dalam enam macam varian, yaitu: Salmon Teriyaki tersedia dalam 68 gr, Saus Krim dan Bawang tersedia dalam 55 gr, Rumput Laut tersedia dalam 55 gr dan 68 gr, Madu Mentega tersedia dalam 55 gr, Sapi Panggang tersedia dalam 68 gr, dan terakhir rasa Klasik tersedia dalam $68 \mathrm{gr}$. 


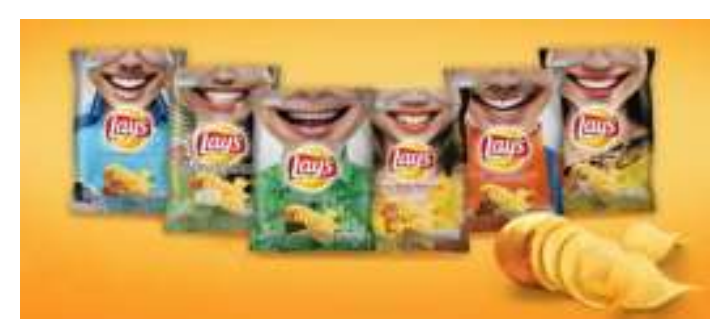

Gambar.1. Varian Rasa Makanan Ringan Lay's Sumber Gambar : www.indofood.com

\subsection{Perubahan Desain Kemasan Lay's}

Kemasan awal Lay's hanya menampilkan logo besar pada bagian atas kemasan serta menunjukan foto yang mewakili informasi produk berupa kentang yang dipotong tipis serta varian rasa yang tersedia. Untuk pembeda setiap varian ditandai oleh warna kemasan juga.
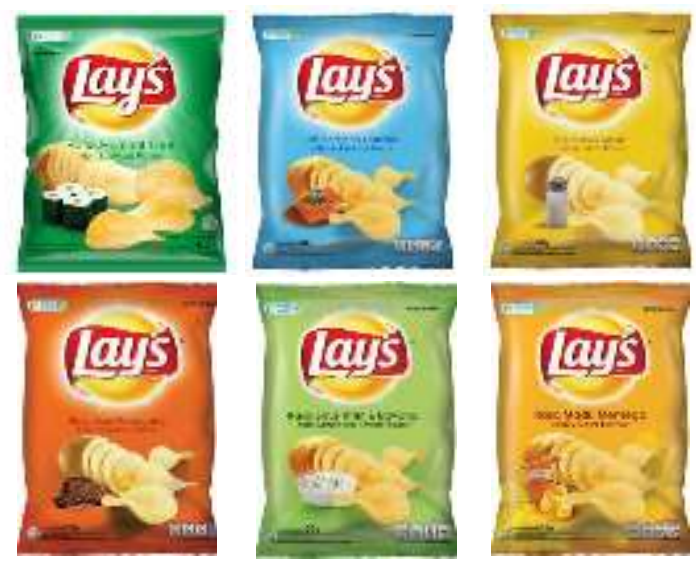

Gambar. 2. Kemasan awal Lay's Sumber Gambar : www.indofood.com

Setelah meluncurkan kemasan terbaru, Lay's menampilkan sebuah foto setengah wajah yang tersenyum yang memenuhi tampilan depan kemasan dengan menggeser logo yang awalnya berada di atas menjadi kecil dan berletak di tengah kemasan. Foto kentang dan varian rasa pun diperkecil namun masih terletak dibawah kemasan. Kemudian menambahkan violator yang menyatakan isi bertambah lebih banyak 15\% pada kemasan yang memiliki berat bersih 68gr saja. Namun warna pada kemasan pada tiap varian rasa tidak berubah.

Dengan menggeser posisi awal logo Lay's serta memperkecil foto kentang serta informasi varian rasa produk, gambar wajah setengah tersenyum ini menjadi display utama dari kemasan Lay's tersebut. Pilihan foto wajah yang ditampilkan oleh Lay's juga memiliki varian foto untuk pria maupun wanita pada semua rasa yang tersedia sehingga tidak terlihat monoton.
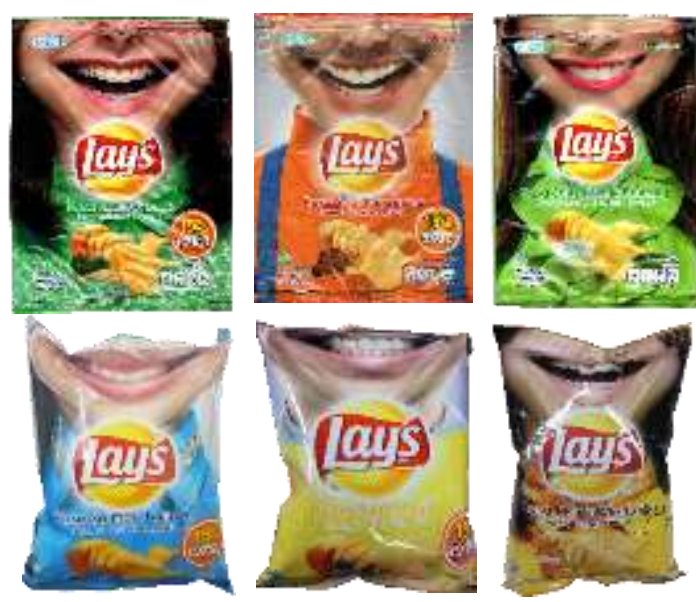

Gambar 3. Kemasan baru Lay's

Sumber Gambar : dokumentasi peneliti

Pada kemasan yang terbaru, tampilan yang menjadi display utama merupakan foto setengah wajah yang tersenyum. Dengan menambahkan foto tersebut, diharapkan konsumen dapat tertarik dengan keunikan dari tampilan rupa kemasan yang berbeda dari lainnya. Foto setengah wajah tersenyum terdiri dari wajah pria dan wanita.

\subsection{Gambar pada kemasan Lay's}

Gambar berupa foto wajah pada kemasan Lay's ini seakan menunjukkan target pengguna produk dengan menggunakan foto model yang sesuai dengan konsumen, sehingga setengah wajah tersebut dipersepsikan konsumen sendiri yang menjadi foto model di kemasan ketika berfoto bersama. 


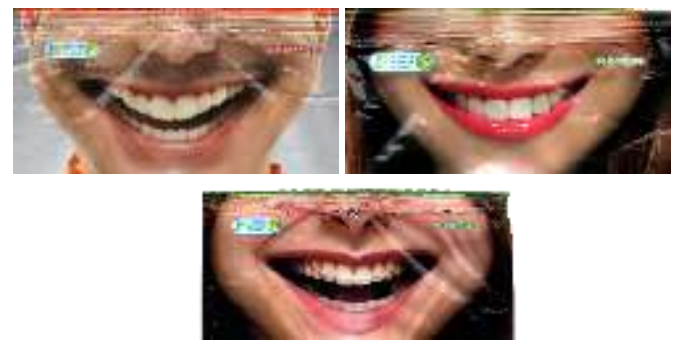

Gambar 4. Beberapa varian foto setengah wajah tersenyum kemasan Lays

Sumber Gambar : dokumentasi peneliti

\subsection{Citra}

Lay's menggunakan sebuah foto setengah wajah yang tersenyum memberikan kesan atau citra yang ceria untuk brand ini. Sesuai dengan citra yang ingin disampaikan Lay's yang membuat orang tersenyum lewat tampilan kemasan terbaru.

\subsection{Tata letak}

Urutan informasi mulai dari yang paling diperhatikan sampai yang tidak terlalu diperhatikan sangat berpengaruh dalam menuntun konsumen untuk membaca urutan tampilan rupa pada desain kemasan. Pada kemasan Lay's, foto wajah tersenyum merupakan perhatian utama dari kemasan tersebut, lalu konsumen diarahkan untuk melihat logo Lay's yang terletak pada tengah kemasan untuk informasi lebih lanjut. Pada tahap selanjutnya, konsumen akan diarahkan kepada violator yang menunjukkan kelebihan dari produk tersebut. Kemudian dilanjutkan pada foto produk dan juga gambar informasi varian rasa yang disediakan.

Sesuai dengan teori tata letak yang telah diuraikan, kemasan Lay's memiliki keberagaman tampilan foto setengah wajah tersenyum yang menjadi fokus utama, sehingga ditampilkan lebih menonjol dari unsur lainnya. Keseimbangan dalam kemasan Lay's ini memiliki komposisi yang tidak kaku dikarenakan tambahan violator yang ada pada sisi kanan bawah sehingga menimbulkan bobot elemen yang tidak sama pada kedua sisi.

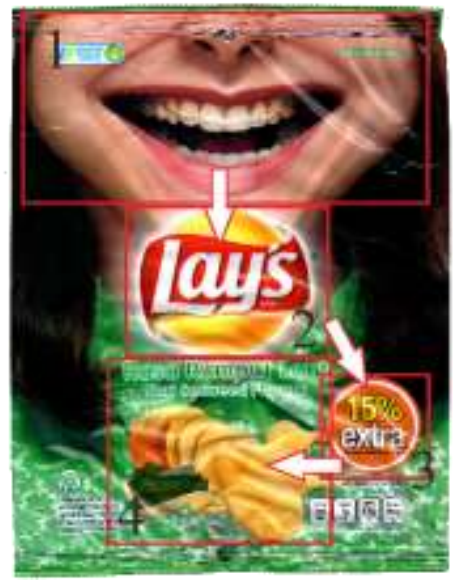

Gambar 5. Arah baca pada tata letak kemasan Lays Sumber Gambar : dokumentasi peneliti

\subsection{Logo pada kemasan Lay's}

Logo Lay's terdiri dari warna merah, gradasi kuning ke oranye dan putih. Tulisan "Lay's" ditulis cetak miring dengan huruf script. Warna merah serta gradasi kuning ke oranye merupakan warna yang tepat untuk menarik perhatian konsumen. Logo ini juga memiliki keterbacaan yang baik karena menggunakan warna putih sehingga membuat warna sekitar lebih terlihat menonjol.

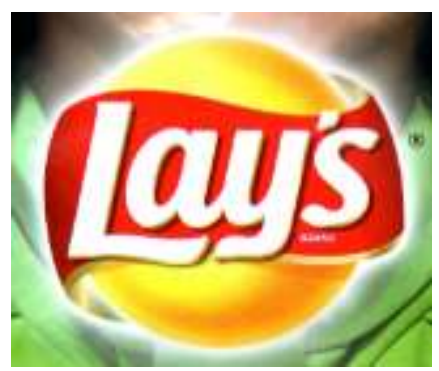

Gambar 6. Logo Lays Terlihat kontras dengan obyek rupa lainnya.

Sumber Gambar : dokumentasi peneliti 


\subsection{Kaitan Gestalt (Closure) pada foto wajah kemasan Lays}

Persepsi yang ditimbulkan ketika melihat foto tersebut merupakan gambar wajah yang tidak utuh atau hanya setengahnya saja yang memperlihatkan sebuah senyum yang lebar sehingga memiliki sedikit unsur karikatur yang menonjolkan bagian mulutnya tersebut.
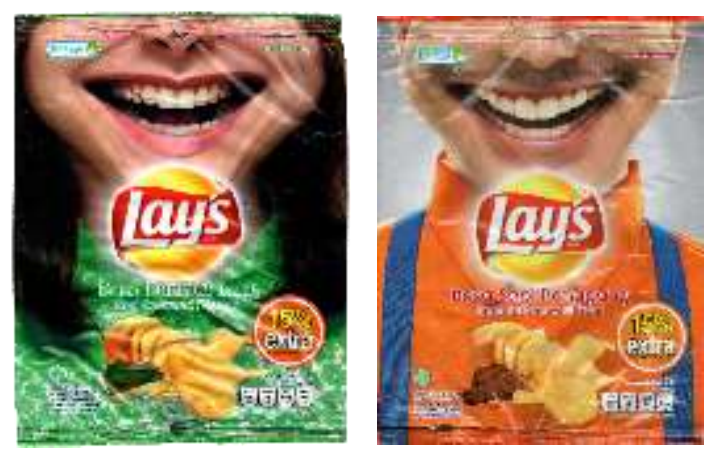

Gambar 7. Foto wajah pada Kemasan Lays ditampilkan tidak utuh

Sumber Gambar : dokumentasi peneliti

Melihat dari kemasan tersebut, dapat disimpulkan bahwa gambar tersebut merupakan foto setengah wajah orang yang sedang tersenyum, meski hanya ditampilkan gambar yang tidak utuh dari keseluruhan wajah. Foto setengah wajah di kemasan Lay's tersebut dapat membuat konsumen tertarik untuk berfoto dan menjadi suatu bagian yang utuh dengan menempelkan kemasan tersebut ke wajah konsumen sehingga terlihat sebagai satu kesatuan yang utuh.

\subsection{Kaitan AISAS pada kemasan} Lay's terhadap minat foto konsumen.

Perubahan tampilan rupa pada kemasan keripik kentang Lay's memperlihatkan bahwa dengan menampilkan foto wajah tersenyum yang berbeda dari kemasan lainnya dapat membuat konsumen menaruh perhatian (Attention). Setelah mendapatkan perhatian, konsumen diarahkan untuk memilih dan mencoba untuk berfoto. Kemasan Lay's memberikan foto setengah wajah yang berbeda-beda pada tiap varian rasa, agar konsumen dapat memilih sesuai dengan minat yang diinginkan (Interest). Setelah menimbulkan ketertarikan pada kemasan Lay's, konsumen dapat melakukan pencarian (Search) untuk informasi lebih lanjut melalui internet seperti di media sosial (facebook, instagram, dan lain-lain) atau mesin pencari seperti google. Setelah yakin dengan keputusan yang ada, konsumen pun memutuskan untuk membeli kemudian melakukan foto bersama dengan kemasan Lay's (Action). Begitu melakukan aksi foto dengan kemasan Lay's tersebut, pada tahap terakhir AISAS yaitu Share, konsumen menyebarkan hasil fotonya ke media sosial seperti facebook atau instagram.

\subsection{Minat foto konsumen sebelum dan sesudah kemasan Lay's berubah setelah ditambahkan unsur Prmosi Penjualan.}

Sebelum tampilan rupa kemasan Lay's dilakukan perubahan, konsumen tidak terdorong untuk berfoto bersama dengan kemasan Lay's tersebut. Tidak ada ajakan kepada konsumen untuk melakukan aksi berfoto dengan kemasan Lay's, karena tampilan rupa lebih didominasi logo Lay's saja. Namun setelah foto setengah wajah tersenyum ditampilkan, terlihat ada ajakan kepada konsumen untuk membuat attention.

Lay's menambahkan gambar tersebut dalam kegiatan promosi penjualan yang memiliki tujuan untuk menciptakan ketertarikan. Selain membuat konsumen tertarik untuk melihat, foto setengah wajah tersenyum juga mampu mengajak kepada sebuah tindakan untuk berfoto. Setelah melakukan foto bersama, konsumen juga akan melakukan tindakan dengan 
membagikan foto tersebut ke internet atau media sosial.

Berikut adalah beberapa foto konsumen yang melakukan foto bersama dengan kemasan Lay's terbaru yang menunjukkan setengah wajah tersenyum, kemudian mengunggah ke beberapa media sosial seperti facebook dan juga instagram.

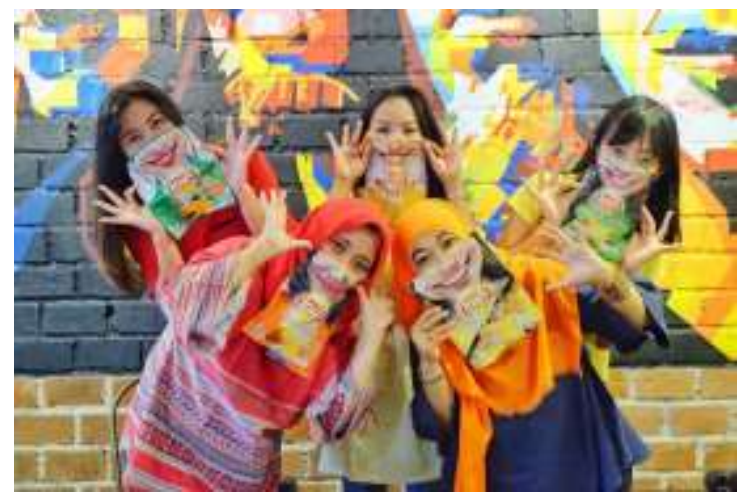

Gambar 8. Foto Konsumen bersama kemasan Lay's di akun medsos Facebook

Sumber Gambar : Facebook Lay's Indonesia
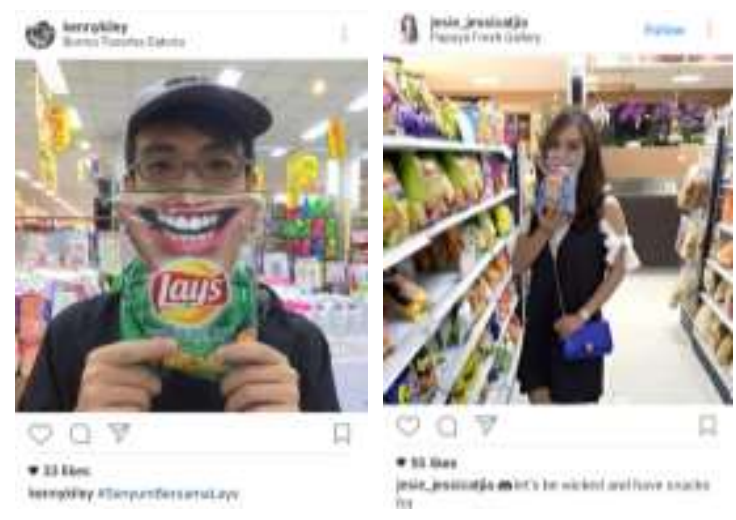

Gambar 9. Foto Konsumen bersama kemasan Lay's di akun Instagram konsumen

Sumber: Instagram konsumen / dokumentasi peneliti

\subsection{Survey Pendapat Konsumen}

Untuk mengetahui pendapat konsumen terhadap kemasan Lay's maka dilakukan survey berupa kuisioner yang di sebarkan melalui media sosial seperti facebook.
Kuisioner yang terkumpul diisi oleh 50 responden dengan usia sekitar 17-29 tahun. Responden diberi beberapa dan memilih jawaban untuk setuju atau tidak setuju. Berikut pertanyaan-pertanyaan yang disampaikan dan jawaban yang diberikan:

1. Menurut anda, bagian yang menjadi perhatian ketika pertama kali melihat kemasan Lay's adalah Ilustrasi / Foto wajah setengah tersenyum $\quad(86 \%$ setuju dan $14 \%$ tidak setuju).

2. Menurut anda, bagian yang menjadi perhatian pertama kali untuk berhenti dan melihat kemasan Lay's adalah Logo Lay's (60\% setuju dan $40 \%$ tidak setuju).

3. Menurut anda, bagian yang menjadi perhatian pertama kali untuk berhenti dan melihat kemasan Lay's adalah Tulisannya (34\% setuju dan 66\% tidak setuju).

4. Menurut anda, bagian yang menjadi perhatian pertama kali untuk berhenti dan melihat kemasan Lay's adalah Warnanya (48\% setuju dan 52\% tidak setuju).

5. Menurut anda, bagian yang membuat anda ingin berfoto atau selfie dengan kemasan Lay's adalah Ilustrasi / Foto wajah setengah tersenyum $(80 \%$ setuju dan 20\% tidak setuju).

6. Apakah Anda akan mencari informasi tentang kemasan Lay's tersebut ke Supermarket (70\% setuju dan 30\% tidak setuju).

7. Apakah Anda akan mencari informasi tentang kemasan Lay's tersebut di Iklan (66\% setuju dan 34\% tidak setuju).

8. Apakah Anda akan mencari informasi tentang kemasan Lay's tersebut di Internet (google) $(68 \%$ setuju dan $32 \%$ tidak setuju).

9. Apakah Anda akan mencari informasi 
tentang kemasan Lays tersebut di Media Sosial (Facebook/ Instagram/ dll) (68\% setuju dan 32\% tidak setuju).

10. Setelah membeli, anda akan selfie dengan kemasan Lays tersebut. (64\% setuju dan $36 \%$ tidak setuju).

11. Apakah setelah anda berfoto dengan kemasan Lays, anda akan mengunggah foto tersebut ke internet atau media sosial seperti facebook / instagram / dll (60\% setuju dan $40 \%$ tidak setuju).

Kesimpulan dari kuisioner yang dibagikan kepada responden tentang kemasan Lay's terbaru menunjukkan bahwa kemasan Lay's terbaru ini mampu menarik perhatian. Tampilan rupa yang menunjukkan foto wajah merupakan daya tarik utama dari kemasan Lay's sehingga menimbulkan ketertarikan lebih lanjut dan berakhir pada minat untuk berfoto bersama dan mengunggahnya ke media sosial.

Sesuai dengan teori AISAS yang mendasari pertanyaan yang diajukan untuk kuisioner, yang menjadi perhatian utama (attention) dan tertarik (interest) untuk berfoto dari kemasan Lays adalah foto wajah. Kemudian masuk pada tahapan mencari (search), responden lebih memilih untuk langsung mencari ke pasar swalayan, dan melakukan tindakat (action) untuk membeli kemudian berfoto bersama dengan kemasan Lay's, lalu mengunggahnya ke media sosial (share) seperti facebook atau Instagram.

\section{KESIMPULAN}

Desain kemasan snack Lay's dapat menarik minat konsumen dengan membuat diferensiasi desain kemasan produk dari kompetitor lainnya. Lay's melakukan promosi penjualan dengan melakukan perubahan desain kemasan yang menunjukkan setengah wajah yang tersenyum untuk dapat menarik konsumen. Foto wajah yang ditampilkan sebagai display utama kemasan Lay's mewakili target pengguna produk. Keberagaman foto senyuman yang ditampilkan baik wanita atau pria membuat konsumen menjadi tertarik untuk memilih.

Lay's mampu menarik perhatian (Attention) konsumen dengan foto tersebut kemudian menimbulkan minat (Interest) lebih lanjut dengan pilihan foto beragam sesuai preferensi konsumen. Kemudian konsumen mencari (Search) informasi lebih lanjut tentang Lays, lalu melakukan tindakan (Action) untuk membeli dan berfoto bersama dengan kemasan Lay's dan tahap terakhir mengunggahnya ke media sosial (Share).

Pembuktian yang lebih lanjut, dari hasil kuisioner yang disebarkan menyatakan bahwa kemasan mampu menarik perhatian dan membangkitkan minat konsumen untuk membeli, sampai pada tindakan untuk berfoto bersama kemudian mengunggahnya pada media sosial. 


\section{DAFTAR PUSTAKA}

[1] Adityawan, Arief dan Tim Litbang Concept. 2010. Tinjauan Desain Grafis Dari Revolusi Industri Hingga Indonesia Kini. PT Concept Media, Jakarta

[2] Creswell, John W. 2013. Research Design Pendekatan Kualitatif, Kuantitatif, dan Mixed. Pustaka Pelajar, Yogyakarta

[3] Engel, dkk. 1994. Consumer Behaviour. Binarupa Aksara, Jakarta

[4] Harsanto, Prayanto W. 2016. Retorika Visual Fotografis dalam Iklan Koran. Penerbit PT Kanisius., Yogyakarta

[5] Jefkins, Frank F. 1995. Periklanan. Penerbit Erlangga, Jakarta

[6] Julianti, Sri. 2014. The Art of Packaging. Penerbit PT Gramedia Pustaka Utama, Jakarta

[7] Klimchuck, Marianne Rosher dan Krasovec, Sandra A. 2006. Desain Kemasan. Penerbit Erlangga, Jakarta

[8] Lester, Paul Martin. 2011. Visual Communication : Image with Messages. Wadsworth, USA

[9] Phalosa, Vinna. 2013. Perubahan ciri merek es krim magnum. Skripsi. Institut Teknologi Harapan Bangsa, Bandung

[10] Sugiyama, Kotaro dan Andree, Tim. 2011. The Dentsu Way: Secret of Cross Switch Marketing from the World's Most Innovative Advertising Agency. McGraw Hill Professional, USA

[11] Suryani, Tatik. 2008. Perilaku Konsumen Implikasi pada Strategi Pemasaran. Graha Ilmu, Yogyakarta

[12] Wahyudi, Nanang \& Satriyono, Sonny. 2017. Mantra Kemasan Juara. PT Elex Media Komputindo, Jakarta 
Wayang adalah seni pertunjukkan dengan menggunakan bentuk figur yang diolah dari pahatan kulit atau kayu, berkembang dan sangat populer di tanah Jawa dan Bali. Kata Wayang berasal dari kata "Ma Hyang" yang artinya menuju kepada Tuhan Yang Maha Esa. Pada 7 Nopember 2003 lembaga kebudayaan UNESCO menetapkan Wayang sebagai sebuah warisan mahakarya dunia yang tak ternilai dalam seni bertutur (Masterpiece of Oral and Intangible Heritage of Humanity).

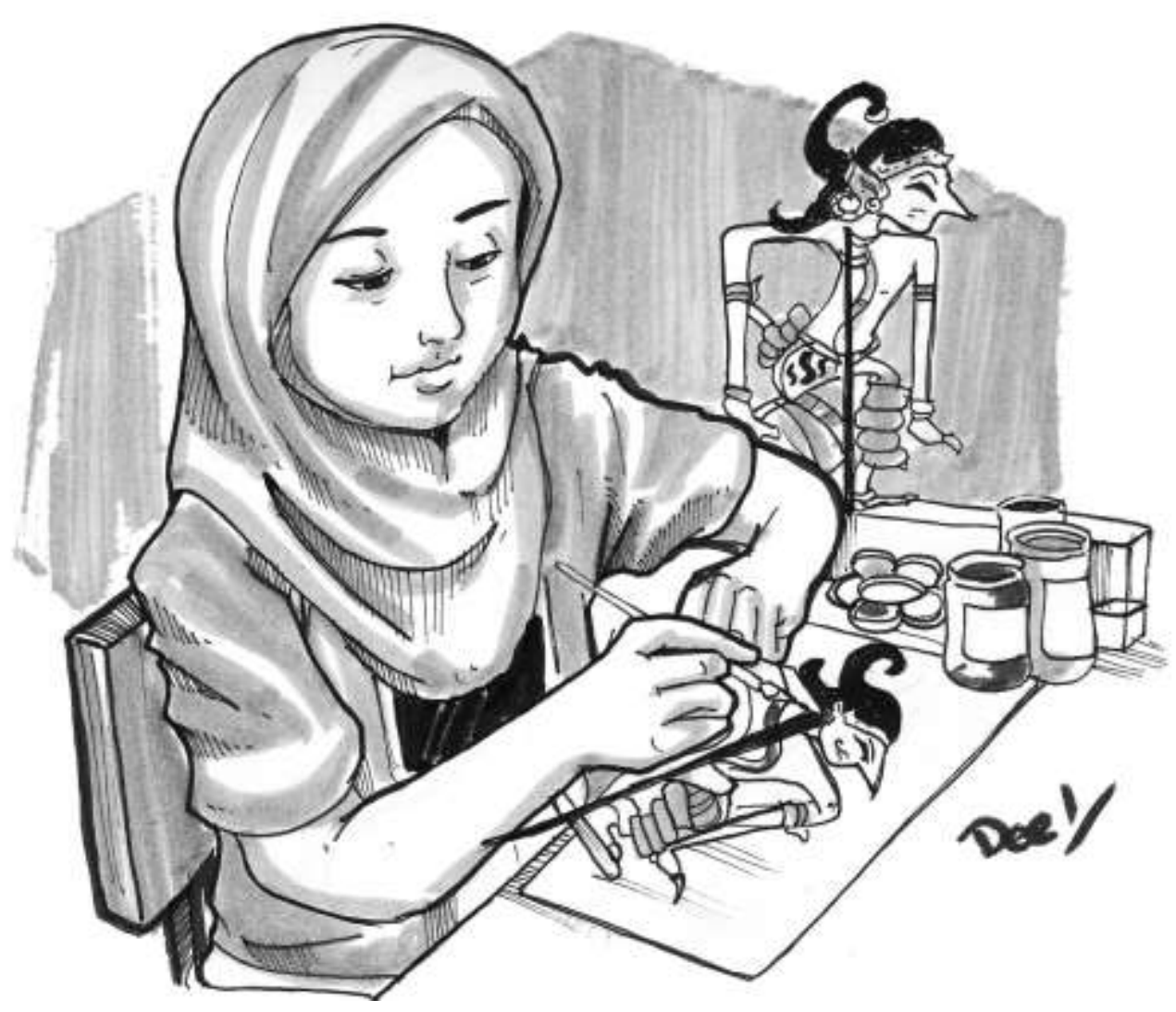

WAYANG TRADISI

ilustrasi oleh Dimas Krisna Aditya, Desember 2016 